\title{
Mowing regime has different effects on reed stands in relation to habitat
}

\author{
Simona Fogli ${ }^{a}$, Lisa Brancaleoni ${ }^{\mathrm{a}}$, Carla Lambertini ${ }^{\mathrm{b}}$, Renato Gerdol ${ }^{\mathrm{a}, *}$ \\ ${ }^{a}$ Department of Life Sciences and Biotechnology, University of Ferrara, Corso Ercole I d'Este 32, 44121 Ferrara, Italy \\ ${ }^{\mathrm{b}}$ Department of Biological Sciences, Plant Biology, Aarhus University, Aarhus C, Denmark
}

\section{A R T I C L E I N F O}

\section{Article history:}

Received 1 July 2013

Received in revised form

5 November 2013

Accepted 1 January 2014

Available online

\section{Keywords:}

Competition

Conservation

Fen meadow

Management

Priority habitat

Wetland

\begin{abstract}
A B S T R A C T
Reed (Phragmites australis) is widespread in aquatic habitats in Europe where it plays an important ecological role, especially as stabilizer of lake and river shores and as filter against pollutants. Reed is also abundant in ecotones towards terrestrial habitats, especially fen meadows, where its expansion can outcompete rare slowly-growing fen species. Therefore, defining appropriate guidelines for managing reed in wetlands has to consider differences in the ecological roles that reed plays in different wetland habitats. In a small pre-alpine lake in N Italy, we mowed reed stands in three plant communities located along a transect from the lake shore to the periphery. In each community, three areas were subjected to reed mowing in late winter, as traditionally done in the past. Three additional areas were subjected to mowing in winter and summer, while three areas served as un-treated controls. Summer mowing was carried out in August, when the nesting period of birds was concluded. Mowing in winter did not affect reed aboveground biomass ( $\mathrm{RAB})$ in any community but enhanced the efficiency of removing nutrients by reducing litter accumulation in the soil. Mowing in winter and summer only slightly decreased RAB in the riparian community, not at all in the intermediate community but significantly diminished RAB in fen meadows. Phosphorus deficiency and/or reduced competition with other species probably accounted for $\mathrm{RAB}$ reduction in fen meadows. In conclusion, winter mowing can be overall recommended for preventing eutrophication of littoral habitats while summer mowing is advisable for preventing reed expansion in fen meadows. However, the timing of summer mowing has to be defined considering all requirements needed for optimal management of each individual site.
\end{abstract}

(ㄷ) 2014 Published by Elsevier Ltd.

\section{Introduction}

Defining appropriate guidelines for protection and/or restoration of wetland ecosystems represents an urgent need towards a sustainable management of wetlands, because of their ecological function and economic value (Erwin, 2009). Phragmites australis (Cav.) Trin. ex Steudel (common reed, henceforth called reed) is a vascular plant, with cosmopolitan distribution range, that forms extensive stands in several types of aquatic habitats, especially lake and river shores, marshes, coastal brackish swamps and lagoons (Engloner, 2009). The ecological importance of reed stands is widely acknowledged (Ostendorp, 1993). In particular, dense reed populations in aquatic habitats act an effective filter against pollutants, thus preserving water quality (Bonanno, 2011; Zhao et al.,

\footnotetext{
* Corresponding author. Tel.: +39 (0)532 293775; fax: +39 (0)532 208561.

E-mail addresses: fgs@unife.it (S. Fogli), bcl@unife.it (L. Brancaleoni), carla. lambertini@biology.au.dk (C. Lambertini), grn@unife.it (R. Gerdol).
}

2012). Furthermore, reed stands stabilize river and lake margins (Ostendorp, 1999; Lövstedt and Larson, 2010) and represent key habitats for wildlife, especially nesting birds (Poulin et al., 2002, 2010). For these reasons, researchers are paying much attention to investigate the causes of extensive reed die-back observed in reed-dominated freshwater ecosystems (Brix, 1999; Reale et al., 2012), but also in brackish coastal wetlands (Fogli et al., 2002).

Even if reed-dominated stands are typical of aquatic habitats, reed is also widespread in ecotones between aquatic and terrestrial habitats. In these ecosystems, increased nutrient load has often been found to enhance reed expansion in many regions outside Europe, from North America (Findlay et al., 2003; Kettenring et al., 2011), to East Asia (Karunaratne et al., 2004a) and South Africa (Russell and Kraaij, 2008). Eutrophication of European wetlands usually enhanced reed expansion into fen meadows (Van Duren and Pegtel, 2000; Güsewell, 2003). The main cause responsible for eutrophication of fen meadows consists in leaching of nutrients, especially nitrogen $(\mathrm{N})$ but also phosphorus $(\mathrm{P})$ and potassium from arable fields. Therefore, low productive ecosystems such as fen 
meadows can become more accessible to reed if nutrient levels increase (Brülisauer and Klötzli, 1998). Higher nutrient status enhances growth of reed much more than that of intrinsically slowlygrowing fen species, which are thus out-competed by reed and can even disappear. This eventually implies habitat degradation, loss of rare species and lowered biodiversity in fen meadows (Ludwig et al., 2003), that are listed among priority habitats in the European legislation. Abandonment of the traditional practice of periodic mowing of the standing crop may further enhance reed expansion in European fen meadows. Several studies have reported reduced reed aboveground production in reed stands subjected to experimental mowing, although the amount of growth depression varied in relation to timing of the cuts (Mochnacka-Lawacz, 1974; Husák, 1978; Güsewell, 2003). An explanation of reed growth reduction after cutting the aboveground tissues resides in the removal of reserve carbohydrates before replenishing the rhizomes (Karunaratne et al., 2004b). The effects of mowing on reed aboveground production can, further, depend on water level. For example, Rolletschek et al. (2000) and Russell and Kraaij (2008) found stronger negative effects of mowing on reed growth in flooded areas probably because of impaired convective ventilation followed by hypoxia in the basal plant parts. Similarly, Próchnicki (2005) observed reduced growth rates in reed stands subjected to frequent flooding. Saltmarsh et al. (2006) reported reduced $\mathrm{CO}_{2}$ assimilation rates in reed plants under permanent waterlogging.

The management of reed populations can have differing goals, essentially depending on if reed expansion is desired or not (Güsewell and Klötzli, 2000). This study was set up in order to investigate the effects of mowing on reed growth across a water-level gradient in a freshwater wetland in Northern Italy. We aimed to assess if reed mowing could be regarded as an appropriate management tool across the entire water-level gradient. We also aimed to evaluate the differential effect of the traditional winter cut on reed growth and nutrient removal versus a complementary cut treatment in summer. Our final goal was to define guidelines for managing reed populations for the sake of preserving reed stands in littoral areas and preventing reed invasion in the surrounding fen meadows.

\section{Materials and methods}

\subsection{The study site}

The study was conducted at Lago di Alserio $\left(45^{\circ} 47^{\prime} \mathrm{N} 9^{\circ} 13^{\prime} \mathrm{E}\right.$; $260 \mathrm{~m}$ a.s.l.), a small shallow lake $\left(1.23 \mathrm{~km}^{2}\right.$; maximum depth $c .8$ $\mathrm{m})$ in Northern Italy, close to the southern slopes of the Alps $c$. $35 \mathrm{~km}$ North of Milan. The lake, of glacial origin, is located in an inter-moraine basin on carbonate bedrock. The climate is temperate-humid, with mean annual temperature of $c .12{ }^{\circ} \mathrm{C}$. The mean annual precipitation is $c .1400 \mathrm{~mm}$, most of which is received in spring, summer and autumn.

A waterplant community, dominated by Nuphar lutea and Nymphaea alba (Myriophyllo-Nupharetum), is settled in the water body where the mean water depth ranges from c. $2 \mathrm{~m}$ to $c .0 .5 \mathrm{~m}$ (Gerdol, 1987). The lake shore is covered by almost pure reed stands (Phragmitetum australis) in front of the free water and by reed stands rich in Calamagrostis canescens (Peucedano-Calamagrostietum canescentis) just behind. At greater distance from the shore the vegetation is mainly comprised of fen meadows, with two communities: the Caricetum elatae with Carex elata and the Selino-Molinietum caeruleae with Molinia caerulea as dominant species, respectively. Both communities are partly invaded by reed. Fragments of alluvial forests (Alno-Fraxinetum oxycarpae) and patches of ruderal vegetation rich in Filipendula ulmaria also occur in this area (Gerdol, 1987).

During the last decades the lake experienced a transition from mesotrophic to eutrophic conditions, because of intensive fertilization of the surrounding cropland and ineffective wastewater treatment. Nowadays, the water $\mathrm{pH}$ is alkaline and nutrient concentrations are high. In particular, concentrations of reactive $\mathrm{P}$ as high as $900 \mu \mathrm{g} \mathrm{L}^{-1}$ have been recorded during the summer months in the anoxic bottom layers of the water body (Rogora et al., 2002). The traditional practice of managing the littoral vegetation has been almost totally abandoned since about 30 years. Previously, reed stands were regularly harvested in winter in order to prevent fires. Reed was occasionally mown in late summer as well. Eutrophication and abandonment of traditional land-use practices caused a gradual expansion of reed into the fen meadows. This implied a significant reduction in the area covered by priority habitats and a strong decline, or even disappearance, of rare and endangered plant species such as Drosera rotundifolia, Euphrasia marchesettii and Cicuta virosa (Gerdol, 1987).

\subsection{Experimental set-up}

The experimental set-up was designed after a preliminary survey carried out in summer 1999 . We initially planned to locate a number of small $(1 \times 1 \mathrm{~m})$ experimental plots across a transect from the lake shore to the periphery. However, some assays showed that mowing brought about serious disturbance, especially at the edge of the mown areas. We, hence, decided to locate a smaller number of larger $(10 \times 10 \mathrm{~m})$ areas in the most representative plant communities. In October 1999, three experimental areas were placed in each of the following three communities: the Phragmitetum australis (PA), the Peucedano-Calamagrostietum canescentis (PC) and the Selino-Molinietum caeruleae (SM). These areas were subjected to the following treatments during the period 2000-2002:

Un-treated control (C).

Winter mowing (W). All aboveground plant parts were manually mown and harvested in winter 2001 and winter 2002.

Winter + summer mowing (WS). All aboveground plant parts were manually mown in winter, as for the $\mathrm{W}$ treatment, and also in summer 2000 and summer 2001.

As a result, all treated plots experienced two cycles of W or WS cuts (Appendix). The winter cut was carried out in February, when the soil was frozen, as usually done in the past. The summer cut was carried out in early August when the nesting period of birds was concluded. In July 2000 three $1 \times 1 \mathrm{~m}$ plots were set up in each of the nine experimental areas for measurements of reed aboveground biomass (RAB).

Water-table depth was measured manually, twice during the growing season 2002 (May and July, respectively), in a 50-cm long perforated pipe at each of the nine experimental areas.

In May 2002 twelve additional $1 \times 1 \mathrm{~m}$ plots were set up in each of the nine experimental areas for subsequent samplings and measurements, according to the following protocol.

Three replicate soil samples in each area served for sampling soil. At each replicate plot, five soil cores were dug in July 2002 from the soil to a depth of $c .10 \mathrm{~cm}$ and bulked into a composite sample. The choice of the plots was subjective. However, all plots were located in homogeneous parts of the experimental areas with no apparent signs of damage to the vegetation. Three replicate plots in each area were used for sampling reed leaves. To this aim, the third leaf from ground was collected in July 2002 from five un-damaged reed culms and bulked into a composite sample. This material served for determining $\mathrm{N}$ and $\mathrm{P}$ concentrations. Three replicate plots in each area were used for sampling reed rhizomes. In July 2002 three 15 -cm long parts were cut, just below the first branch, from 2 to 3 old healthy-looking horizontal rhizomes (Čížková and Bauer, 1998) for determining starch concentration. Three replicate plots in each area were used for measurements of RAB. 


\subsection{Chemical analyses}

The soil samples were stored at $4{ }^{\circ} \mathrm{C}$ until analyses. In order to minimize oxidation, the analyses were carried out within one day from sample collection. Concentrations of extractable ammonium $\left(\mathrm{NH}_{4}{ }^{+}\right)$were determined colorimetrically at $690 \mathrm{~nm}$ wavelength, on $6 \% \mathrm{KCl}$ digests. Concentrations of extractable nitrate $\left(\mathrm{NO}_{3}^{-}\right)$were determined colorimetrically at $420 \mathrm{~nm}$ wavelength, on distilled water digests. Concentrations of extractable phosphate $\left(\mathrm{PO}_{4}{ }^{3-}\right)$ were determined colorimetrically at $700 \mathrm{~nm}$ wavelength, on digests obtained using the Truog's solution (Allen, 1989).

Total $\mathrm{N}$ concentrations in reed leaves were determined by the Kjeldahl method after digesting c. $0.5 \mathrm{~g}$ dry weight in selenous sulphuric acid (Allen, 1989). Total P concentrations in reed leaves were determined colorimetrically, after digesting c. $0.5 \mathrm{~g}$ dry weight in nitric acid, by means of a spectrophotometer at $700 \mathrm{~nm}$ wavelength, according to the molybdovanadate method (Allen, 1989).

For determining starch concentration, the rhizome samples were washed with distilled water and stored at $-20{ }^{\circ} \mathrm{C}$ until analysis. After drying $\left(105^{\circ} \mathrm{C}\right.$ for $\left.24 \mathrm{~h}\right)$ and grinding, the material was heated for $15 \mathrm{~min}$ in a boiling bath. Starch was extracted with $65 \% \mathrm{HClO}_{4}$ and its concentration was determined colorimetrically at $680 \mathrm{~nm}$ wavelength (Allen, 1989).

\subsection{Species composition and aboveground biomass}

RAB was assessed in July 2000 and 2002 according to Güsewell and Klötzli's (1997) equation:

$\operatorname{RAB}\left(\mathrm{g} \mathrm{m}^{-2}\right)=$ mean shoot density $\left(\mathrm{m}^{-2}\right) \times$ average dry weight per shoot $(g)$

The average dry weight of reed shoots was obtained by regression analyses of mean culm length $(\mathrm{m})$ and mean basal diameter $(\mathrm{mm})$. The regressions were performed separately for each plot in 2000 and 2002 and were calibrated based on 15 shoots harvested and weighed on each occasion in all plots. Shoot length was measured from the soil to the base of the inflorescence or to the apical leaf. Diameter was measured in the middle of the fourth internode. Dry weight was measured after drying the shoots at $105^{\circ} \mathrm{C}$ for $24 \mathrm{~h}$.

In July 2002, the aboveground biomass of all other species was calculated by harvesting the standing crop in four $50 \times 50 \mathrm{~cm}$ quadrats randomly located in each area. The aboveground material of all species was bulked, dried at $105^{\circ} \mathrm{C}$ for $24 \mathrm{~h}$ and weighed.

\subsection{Statistics}

Our sampling design did not allow us to obtain true independent replicates. On the other hand, a larger number of experimental areas would be unmanageable. In order to avoid distortions deriving from pseudoreplication (Schank and Koehnle, 2009), we thus run for all variables hierarchical ANOVAs with replicates nested within the experimental areas. Significance of differences among means were assessed using the Tukey's post-hoc test. All statistics were calculated using the software Statistica 6.0 (StatSoft $\odot$, Tulsa, OK, USA).

\section{Results}

\subsection{Water-table depth and soil chemistry}

Water-table depth decreased from PA to PC and SM (Table 1). At the beginning of the growing season (May), the soil was flooded in PA and PC, but in July the water table was below ground in all communities. In July the treatments affected water- table depth differently in the three communities as mowing raised the water table in PA and PC but lowered the water table in SM (Table 1).

Soil chemistry varied considerably among communities but was not affected by treatment (Table 2). Soil $\mathrm{NH}_{4}{ }^{+}$concentration differed neither among communities $\left(F_{2,13}=0.45, P=0.65\right)$ nor with treatment $\left(F_{2,13}=0.81, P=0.47\right)$. In contrast, soil $\mathrm{NO}_{3}^{-}$concentration presented significant effects of community $\left(F_{2,13}=5.80\right.$, $P=0.01)$ although being unaffected by treatment $\left(F_{2,13}=2.62\right.$, $P=0.11)$. Soil $\mathrm{NO}_{3}^{-}$concentration was overall highest in SM, especially in WS (Table 2). Soil $\mathrm{PO}_{4}{ }^{3-}$ concentration differed dramatically among communities $\left(F_{2,13}=777.19, P<0.001\right)$, with much higher values in PA compared with PC and SM (Table 2) but did not change in relation to treatment $\left(F_{2,13}=0.39, P=0.68\right)$.

\subsection{Plant chemistry}

Nitrogen and $\mathrm{P}$ concentrations in reed leaves differed significantly among communities $\left(F_{2,22}=23.69, P<0.001\right.$ for $\mathrm{N}$ and $F_{2,22}=16.61, P<0.001$ for $\left.P\right)$ but were unaffected by treatment $\left(F_{2,22}=1.83, P=0.20\right.$ for $\mathrm{N}$ and $F_{2,22}=0.92, P=0.41$ for $\left.\mathrm{P}\right)$. Both $\mathrm{N}$ and $\mathrm{P}$ presented highest foliar concentrations in $\mathrm{PA}$, while $\mathrm{P}$ had lowest foliar concentrations in SM (Fig. 1a, b). The N : P ratio in reed leaves also varied significantly among communities $\left(F_{2,22}=20.75\right.$, $P<0.001$ ), with highest values in SM (Fig. 1c) and was overall unaffected by treatment $\left(F_{2,22}=1.23, P=0.31\right)$.

Starch concentration in reed rhizomes varied with community $\left(F_{2,22}=8.95, P=0.002\right)$ and treatment $\left(F_{2,22}=5.07, P=0.02\right)$. Starch concentration was highest in SM (Table 3 ). Treatment increased starch concentrations most strongly in SM with two cuts (WS), to a lesser extent in PC but not in PA (Table 3).

\subsection{Biomass}

RAB differed significantly among communities $\left(F_{2,48}=46.53\right.$, $P<0.001)$ with highest values in PA and lowest values in SM (Table 4). Treatment significantly affected $\operatorname{RAB}\left(F_{2,24}=3.97\right.$, $P=0.03$ ), with lower values in WS compared to $C$ and $W$. Mowing affected RAB in 2002 but not in 2000 (effect of year: $F_{1,48}=7.12$, $P=0.001$ ). Indeed, WS mowing decreased $P$. australis biomass in 2002. Such effect was significant for PA and even more for SM (Table 4).

The biomass of other species was negligible (always $<1 \%$ of reed biomass) in PA, independent of treatment and was overall modest

Table 1

Water-table depth $(\mathrm{cm})$ in the three communities during May and July. Negative values indicate water table below ground.

\begin{tabular}{clcr}
\hline & & May & July \\
\hline PA & C & 8 & -7 \\
& W & 8 & -6 \\
PC & WS & 8 & -3 \\
& C & 2 & -11 \\
& W & 2 & -8 \\
SM & WS & 2 & -5 \\
& C & -3 & -7 \\
& W & -3 & -8 \\
& WS & -4 & -11 \\
\hline
\end{tabular}

Abbreviations for communities.

PA: Phragmitetum australis.

PC: Peucedano-Calamagrostietum canescentis.

SM: Selino-Molinietum caeruleae.

Abbreviations for treatments.

$C$ : un-treated control.

W: one cut (winter).

WS: two cuts (winter + summer). 
Table 2

Mean ( \pm SE; $n=3$ ) concentrations of nutrients in soils from three communities. There were no treatment-related differences in the concentrations of any nutrient. Abbreviations for communities and treatments as in Table 1.

\begin{tabular}{cllll}
\hline & & $\mathrm{NH}_{4}^{+}\left(\mu \mathrm{g} \mathrm{g}^{-1}\right)$ & $\mathrm{NO}_{3}^{-}\left(\mu \mathrm{g} \mathrm{g}^{-1}\right)$ & $\mathrm{PO}_{4}{ }^{3-}\left(\mu \mathrm{g} \mathrm{g}^{-1}\right)$ \\
\hline $\mathrm{PA}$ & $\mathrm{C}$ & $1.73 \pm 0.02$ & $1.39 \pm 0.05$ & $22.63 \pm 0.07$ \\
& $\mathrm{~W}$ & $1.71 \pm 0.01$ & $2.23 \pm 0.06$ & $21.22 \pm 0.30$ \\
& $\mathrm{WS}$ & $1.07 \pm 0.05$ & $1.32 \pm 0.01$ & $19.99 \pm 0.07$ \\
$\mathrm{PC}$ & $\mathrm{C}$ & $1.65 \pm 0.08$ & $2.76 \pm 0.07$ & $1.51 \pm 0.20$ \\
& $\mathrm{~W}$ & $1.53 \pm 0.10$ & $1.36 \pm 0.26$ & $1.48 \pm 0.05$ \\
& $\mathrm{WS}$ & $1.63 \pm 0.18$ & $2.70 \pm 0.10$ & $3.63 \pm 0.31$ \\
$\mathrm{SM}$ & $\mathrm{C}$ & $0.45 \pm 0.02$ & $3.08 \pm 0.03$ & $0.75 \pm 0.41$ \\
& $\mathrm{~W}$ & $1.44 \pm 0.01$ & $1.86 \pm 0.07$ & $0.73 \pm 0.03$ \\
& $\mathrm{WS}$ & $2.13 \pm 0.01$ & $4.26 \pm 0.11$ & $0.98 \pm 0.02$ \\
\hline
\end{tabular}

in PC as well ( $<10 \%$ of reed biomass). Conversely, other species accounted for $>50 \%$ of total community biomass in SM, where mowing increased the biomass of other species by $c$. $29 \%$ in $\mathrm{W}$ and $c$. $44 \%$ in WS. Such increase was principally determined by increased frequency of abundant fen species, especially Carex elata and Carex

(a)

$\mathbf{N}$ concentration

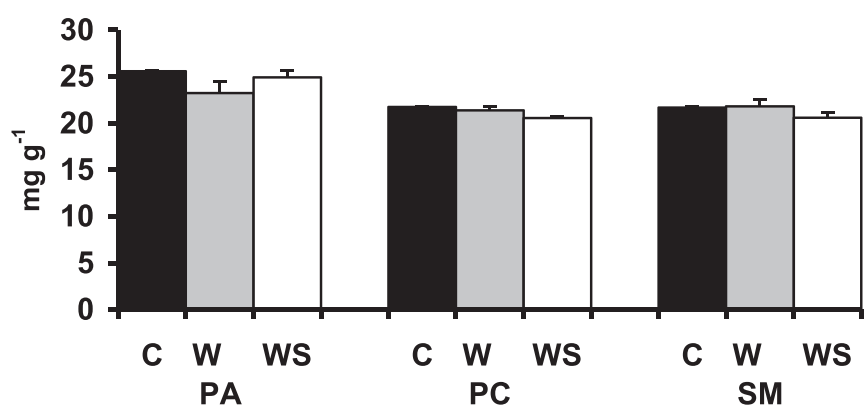

(b)

P concentration

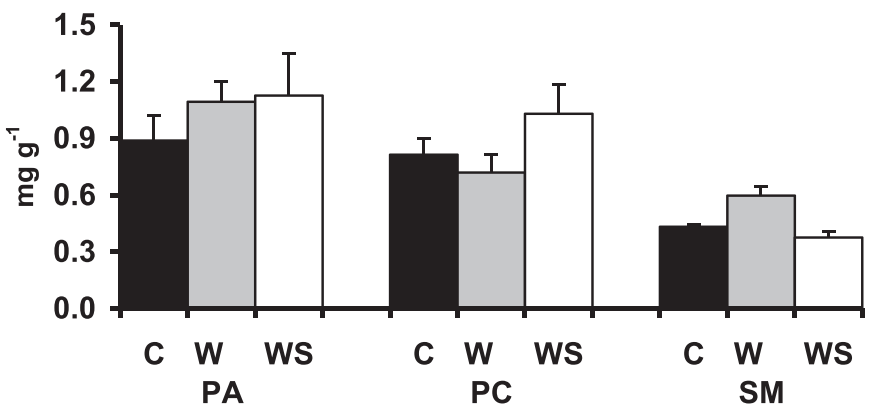

(c)

$\mathbf{N}: \mathbf{P}$

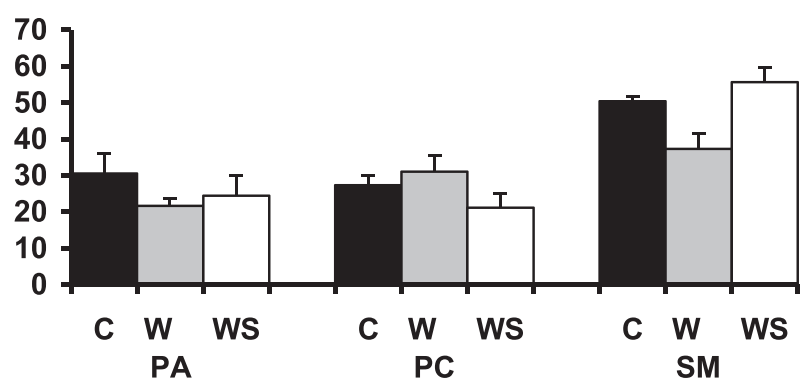

Fig. 1. Mean ( + SE; $n=3$ ) $\mathrm{N}$ and $\mathrm{P}$ concentrations, and $\mathrm{N}: \mathrm{P}$ ratio in reed leaves. The treatments did not affect significantly nutrient concentrations and $\mathrm{N}: \mathrm{P}$ ratio in the three communities. Abbreviations for communities and treatments as in Table 1.
Table 3

Mean $( \pm$ SE; $n=3)$ starch concentration in reed rhizomes from three communities. The means followed by the same letter do not differ at $P<0.05$. Abbreviations for communities and treatments as in Table 1 .

\begin{tabular}{clc}
\hline & & Starch $\left(\mathrm{mg} \mathrm{g}^{-1}\right)$ \\
\hline PA & C & $70 \pm 3.6 \mathrm{~b}$ \\
& W & $48.1 \pm 4.6 \mathrm{bc}$ \\
PC & WS & $58.2 \pm 7.2 \mathrm{~b}$ \\
& C & $29.5 \pm 2.2 \mathrm{c}$ \\
& W & $62.3 \pm 4.9 \mathrm{~b}$ \\
SM & WS & $53.7 \pm 4.0 \mathrm{bc}$ \\
& C & $60.5 \pm 6.1 \mathrm{~b}$ \\
& W & $71.7 \pm 8.4 \mathrm{~b}$ \\
& WS & $152.8 \pm 6.1 \mathrm{a}$ \\
\hline
\end{tabular}

appropinquata, but also by the entry of two rarer fen species, Valeriana dioica and Epipactis palustris, not recorded in 2000. Overall, reed biomass was negatively correlated with the biomass of the other species (Pearson's $r=-0.82, n=9, P=0.002$ ).

\section{Discussion}

\subsection{Ecological role of reed stands and effects of mowing}

The eutrophic condition of the lake was responsible for the high nutrient concentrations in the soil of the shore belt, colonized by dense reed stands (PA). This was reflected in high nutrient, especially P, concentrations in reed plants of the PA community which suggests that reed in this nutrient-rich community principally cycled nutrients based on active uptake from the soil (Kühl et al., 1997; Lippert et al., 1999). Previous studies also reported high efficiency of reed to remove nutrients (Álvarez-Rogel et al., 2006; Zhao et al., 2012), as well as heavy metals (Weis and Weis, 2004), from wetland soils. Foliar P concentrations in PC were much similar to those observed in PA, probably because a higher fraction of $\mathrm{P}$ was recycled from below ground tissues in PC compared with PA. Conversely, $\mathrm{P}$ concentrations in reed leaves in SM were several times lower than those usually recorded at nutrient-rich sites (see, for example: Ho, 1981; Elvisto, 2010; Ruiz and Velasco, 2010). Such low $\mathrm{P}$ concentrations in reed leaves in SM resulted in very high $\mathrm{N}: \mathrm{P}$ ratios, suggesting that $\mathrm{P}$ limits reed growth in this community (Koerselman and Meuleman, 1996).

RAB was always highest in PA and varied considerably between the two years even in the un-treated plots. This probably depended on interannual variations in climate (Dinka et al., 2010) or hydrological conditions (Lawniczak et al., 2010), although disturbance during mowing may have brought about some negative effects on the stands. $W$ mowing did not affect $R A B$ in any

Table 4

Mean ( \pm SE; $n=3$ ) reed aboveground biomass (RAB) in three communities in the growing seasons 2000 and 2002. Within each column, the means followed by the same letter do not differ at $P<0.05$. Abbreviations for communities and treatments as in Table 1.

\begin{tabular}{llcc}
\hline & & RAB $2000\left(\mathrm{~g} \mathrm{~m}^{-2}\right)$ & RAB 2002 $\left(\mathrm{g} \mathrm{m}^{-2}\right)$ \\
\hline PA & C & $982 \pm 130 \mathrm{a}$ & $1844 \pm 245 \mathrm{a}$ \\
& W & $520 \pm 69 \mathrm{ab}$ & $1751 \pm 232 \mathrm{ab}$ \\
PC & WS & $668 \pm 89 \mathrm{ab}$ & $1153 \pm 153 \mathrm{~b}$ \\
& C & $656 \pm 186 \mathrm{ab}$ & $375 \pm 106 \mathrm{c}$ \\
& W & $477 \pm 135 \mathrm{ab}$ & $625 \pm 177 \mathrm{bc}$ \\
SM & WS & $521 \pm 147 \mathrm{ab}$ & $370 \pm 105 \mathrm{c}$ \\
& C & $112 \pm 31 \mathrm{~b}$ & $130 \pm 36 \mathrm{c}$ \\
& W & $99 \pm 27 \mathrm{~b}$ & $56 \pm 16 \mathrm{~cd}$ \\
& WS & $108 \pm 30 \mathrm{~b}$ & $22 \pm 6 \mathrm{~d}$ \\
\hline
\end{tabular}


community but prevented nutrient accumulation in the soil of the shore community (PA) where a greater amount of standing dead biomass was removed by harvesting after the cut. Indeed, nutrients are actively released during decomposition of reed litter but a considerable proportion of $P$ remains trapped in the anaerobic layer of submerged soils (Asaeda et al., 2002). Some studies also observed high efficiency in removing nutrients, especially $P$, without diminishing plant vitality when reed was harvested at the end of the growing season in late summer or autumn (Toet et al., 2005; Ruiz and Velasco, 2010). WS mowing reduced RAB to a greater extent than $\mathrm{W}$ mowing. Growth reduction was stronger at the dry end than at the wet end of the gradient (83\% in SM and $37 \%$ in PA, respectively). If the transport of oxygen to the rhizomes were completely inhibited after the cut this would lead to much a stronger drop in reed aboveground production, especially in PA. A possible explanation of this finding is that even at the wet end of the gradient the soil was flooded only at the beginning of the growing season, so that the basal plant parts did not experience prolonged hypoxia.

Several causes can account for the strong depression of reed aboveground production after WS mowing in SM. Insufficient carbohydrate reserve storage in the rhizomes, as a possible effect of summer cut, did not appear to explain the decreased aboveground biomass of reed plants in SM. Starch concentrations in reed rhizomes at our site were overall low, similar to those recorded at Balaton Lake in Hungary (Čížková et al., 2001) and highest at the nutrient-poor (SM) community. Kubín et al. (1994) also found greater starch reserves in rhizomes at nutrient-poor habitats where reed biomass was lower. We sampled rhizomes for starch analysis in July, when refilling of rhizomes with carbon reserves probably had already started after shoot emergence in spring (Granéli et al., 1992). Interestingly, WS mowing did not diminish but even raised rhizome starch concentrations in SM (Table 2) which suggests that enough reserve were available to support shoot growth later in the season. When nitrate is the prevailing form of available nitrogen, reed accumulates principally starch (Kubín and Melzer, 1996).

Summer cut in open communities (SM) caused higher starch immobilization due to lesser aboveground biomass and consequently reduced carbon demand in slowly-growing aboveground reed tissues. However, we did not determine rhizome biomass, so that we cannot rule out the hypothesis that WS mowing actually reduced the accumulation of reserve in below ground tissues through lower rates of rhizome growth (Asaeda et al., 2006). Phosphorus limitation, as an indirect effect of mowing on watertable depth, may also account for the reduced RAB in SM. WS mowing raised the water table in PA and PC, presumably because the high reed cover in those communities enhances water evapotranspiration (Zhao et al., 2012). Conversely, WS mowing in SM lowered the water table presumably because removing the aboveground biomass allowed the peaty soil to warm up and hence to dry out more rapidly (Price et al., 1998; Gerdol et al., 2008). Although soil drying has been found to reduce $P$ availability for plants because of reduced phosphate diffusion in the soil (Olde Venterink et al., 2001) this did not appear to play a role in our case as soil phosphate concentration in SM was similar to the other communities (Table 2). On the other hand, mowing reed at the peak of the growing season may aggravate P limitation by hindering $\mathrm{P}$ translocation to the rhizomes (Vitousek, 1982).

Lower reed biomass was accompanied by higher mass of other species in the WS plots in SM. This suggests that reed growth is more limited by competition with other plant species than by water shortage at the drier edge of stands (Haslam, 1970; Lenssen et al., 1999). Shading by reed canopy does not seem to limit growth of fen species in reed-invaded stands probably because of the later seasonal growth of reed compared with the other species (Güsewell, 1999). Competition for space probably plays a more important role in limiting fen species after reed invasion. For example, Davies et al. (2010) observed strong competition between reed and native species in a spring fen in Australia and Roth et al. (1999) found open vegetation gaps to represent appropriate sites for successful germination and seedling establishment of fen species. Both processes presumably enhanced fen species after WS mowing in SM. This resulted, on one hand, in increased growth of abundant fen species and, on the other hand, in the establishment of new fen species.

\subsection{Implication for management}

Restoring the traditional practice of mowing reed stands in winter is advisable especially for preventing fires that break out frequently during dry periods in late winter. As fires accelerate rates of litter mineralization, mowing reed in winter is expected to reduce soil nutrient availability thus reducing eutrophication of littoral soils (Wang et al., 2012). Mowing reed in summer, besides winter, is useful for preventing reed invasion in fen meadows although it may be questioned whether August actually represents the best period for summer mowing. Indeed, mowing earlier in summer could be more effective for hampering reed growth as in that period the plants have not yet translocated much carbohydrate storage from rhizomes to aboveground tissues (Asaeda et al., 2006). On the other hand, mowing reed at the time of maximum aerial biomass, before the shoots age and start translocating $\mathrm{P}$ to the rhizomes, could be recommended both to maximize nutrient reduction in nutrient-rich habitats (Ruiz and Velasco, 2010) and for preventing reed invasion in fen meadows. Reed harvesting after the cut is recommendable because it enhances nutrient removal from littoral habitats (Kiedrzyńska et al., 2008). Reed harvesting later in the season may help removing a greater amount of nutrients when reed biomass is highest and senescence has not yet started (Bragato et al., 2006).

\subsection{Concluding remarks}

We could not mow reed until early August because any operation in that period would cause damage to nesting birds. However, mowing reed in August gave a positive result because RAB declined within 2 years which increased competitiveness of fen species against undesired reed invasion. Our data was based on a short (2 years) term experiment. Thus, the dynamics of reed populations should be monitored over a longer period as wetlands are at risk of reed re-invasion in the long term (Ailstock et al., 2001).

In conclusion, winter mowing can be overall recommended for preventing eutrophication of littoral habitats. Summer mowing in fen meadows is advisable although the timing of summer mowing has to be set considering all requirements needed for optimal management of each individual site.

\section{Acknowledgements}

This study was funded by the European Commission, DG XI (LIFE Project on Lago di Alserio, LIFE99NAT/IT/006235, coordinator N. Cannone), Regione Lombardia and Consorzio Parco Valle del Lambro. We thank R. Marchesini for technical assistance in the laboratory and S. Frattini for assistance during the field work. 
Appendix. Time-table of the experimental design (treatment and sampling).

\begin{tabular}{|c|c|c|c|c|c|c|}
\hline & \multicolumn{2}{|c|}{2000} & \multicolumn{2}{|c|}{2001} & \multicolumn{2}{|c|}{2002} \\
\hline & Jul & Aug & Feb & Aug & Feb & Jul \\
\hline \multicolumn{7}{|l|}{ Treatment } \\
\hline Winter mowing (W) & & & $\times$ & & $\times$ & \\
\hline Summer mowing $(S)$ & & $\times$ & & $\times$ & & \\
\hline \multicolumn{7}{|l|}{ Sampling } \\
\hline Reed aboveground biomass (RAB) & $\times$ & & & & & $\times$ \\
\hline Soils & & & & & & $\times$ \\
\hline Leaves & & & & & & $x$ \\
\hline Rhizomes & & & & & & $x$ \\
\hline
\end{tabular}

\section{References}

Ailstock, M.S., Norman, C.M., Bushmann, P.J., 2001. Common reed Phragmites aus tralis: control and effects upon biodiversity in freshwater nontidal wetlands. Restor. Ecol. 9, 49-59.

Allen, S.E., 1989. Chemical Analysis of Ecological Materials, second ed. Blackwell Scientific Publications, Oxford.

Álvarez-Rogel, J., Jiménez-Carceles, F.J., Egea Nicolás, C., 2006. Phosphorus and nitrogen content in the water of a coastal wetland in the Mar Menor lagoon (SE Spain): relationships with effluents from urban and agricultural areas. Water Air Soil. Pollut. 173, 21-38.

Asaeda, T., Nam, L.H., Hietz, P., Tanaka, N., Karunaratne, S., 2002. Seasonal fluctuations in live and dead biomass of Phragmites australis as described by a growth and decomposition model: implications of duration of aerobic conditions for litter mineralization and sedimentation. Aquat. Bot. 73, 223-239.

Asaeda, T., Rajapaske, L., Manatunge, J., Sahara, N., 2006. The effect of summer harvesting of Phragmites australis on growth characteristics and rhizome resource storage. Hydrobiologia 553, 327-335.

Bonanno, G., 2011. Trace element accumulation and distribution in the organs of Phragmites australis (common reed) and biomonitoring applications. Ecotoxicol. Environ. Saf. 74, 1057-1064.

Bragato, C., Brix, H., Malagoli, M., 2006. Accumulation of nutrients and heavy metals in Phragmites australis (Cav.) Trin. ex Steudel and Bolboschoenus maritimus (L.) Palla in a constructed wetland of the Venice lagoon watershed. Environ. Pollut. 144, 967-975.

Brix, H., 1999. The European research project on reed die-back and progression (EUREED). Limnologica 29, 5-10.

Brülisauer, A., Klötzli, F., 1998. Habitat factors related to the invasion of reeds (Phragmites australis) into wet meadows of the Swiss Midlands. Z. Ökol. u. Naturschutz 7, 125-136.

Čížková, H., Bauer, V., 1998. Rhizome respiration of Phragmites australis: effect of rhizome age, temperature, and nutrient status. Aquat. Bot. 61, 239-253.

Čížková, H., Istvánovics, V., Bauer, V., Balázs, L., 2001. Low levels of reserve carbohydrates in reed (Phragmites australis) stands of Kis-Balaton, Hungary. Aquat. Bot. 69, 209-216.

Davies, R.J.P., Mackay, D.A., Whalen, M.A., 2010. Competitive effects of Phragmites australis on the endangered artesian spring endemic Eriocaulon carsonii. Aquat. Bot. 92, 245-249.

Dinka, M., Ágoston-Szabó, E., Szeglet, P., 2010. Comparison between biomass and C, N, P, S contents of vigorous and die-back reed stands of Lake Fertö/Neusiedler See. Biologia 65, 237-247.

Elvisto, T., 2010. Eutrophication level of Phragmites australis habitats at a shallow coastal lake, Paljassaare Peninsula, Tallinn, Estonia. Est. J. Ecol. 59, 83-98.

Engloner, A.I., 2009. Structure, growth dynamics and biomass of reed (Phragmites australis) - a review. Flora 204, 331-346.

Erwin, K.L., 2009. Wetlands and global climate change: the role of wetland restoration in a changing world. Wetl. Ecol. Manage. 17, 71-84.

Findlay, S., Groffman, P., Dye, S., 2003. Effect of Phragmites australis removal on marsh nutrient cycling. Wetl. Ecol. Manage. 11, 157-165.

Fogli, S., Marchesini, R., Gerdol, R., 2002. Reed (Phragmites australis) decline in a brackish wetland in Italy. Mar. Environ. Res. 53, 465-479.

Gerdol, R., 1987. Geobotanical investigations in the small lakes of Lombardy. Atti Ist. Bot. e Lab. Critt. Univ. Pavia 6, 5-49.

Gerdol, R., Bragazza, L., Brancaleoni, L., 2008. Heatwave 2003: high summer temperature, rather than experimental fertilization, affects vegetation and $\mathrm{CO}_{2}$ exchange in an alpine bog. New. Phytol. 179, 142-154.

Granéli, W., Weisner, S.E.B., Sytsma, M.D., 1992. Rhizome dynamics and resource storage in Phragmites australis. Wetl. Ecol. Manage. 1, 239-247.

Güsewell, S., 1999. Shading by Phragmites australis: a threat for species-rich fen meadows? Appl. Veg. Sci. 2, 61-70.

Güsewell, S., 2003. Management of Phragmites australis in Swiss fen meadows by mowing in early summer. Wetl. Ecol. Manage. 11, 433-445.

Güsewell, S., Klötzli, F., 1997. Measuring the abundance of Phragmites communis Trin. in wet meadows- a methodological investigation. Bull. Geobot. Inst. ETH $63,11-24$.
Güsewell, S., Klötzli, F., 2000. Assessment of aquatic and terrestrial reed (Phragmites australis) stands. Wetl. Ecol. Manage. 8, 367-373.

Haslam, S.M., 1970. The performance of Phragmites communis Trin. in relation to water-supply. Ann. Bot.-London 34, 867-877.

Ho, Y.B., 1981. Mineral composition of Phragmites australis in Scottish lochs as related to eutrophication. I. Seasonal changes in organs. Hydrobiologia 85, $227-$ 237.

Husák, Š., 1978. Control of reed and reed mace stands by cutting. In: Dykyjová, D., Kvet, J. (Eds.), Pond Littoral Ecosystems. Springer-Verlag, Berlin, Germany, pp. 404-408.

Karunaratne, S., Asaeda, T., Yutani, K., 2004a. Age-specific seasonal storage dynamics of Phragmites australis rhizomes: a preliminary study. Wetl. Ecol. Manage. 12, 343-351.

Karunaratne, S., Asaeda, T., Yutani, K., 2004b. Shoot regrowth and age-specific rhizome storage dynamics of Phragmites australis subjected to summer harvesting. Ecol. Eng. 22, 99-111.

Kettenring, K.M., McCormick, M.K., Baron, H.M., Whigham, D.F., 2011. Mechanisms of Phragmites australis invasion: feedbacks among genetic diversity, nutrients, and sexual reproduction. J. Appl. Ecol. 48, 1305-1313.

Kiedrzyńska, E., Wagner, I., Zalewski, M., 2008. Quantification of phosphorus retention efficiency by floodplain vegetation and a management strategy for a eutrophic reservoir restoration. Ecol. Eng. 33, 15-25.

Koerselman, W., Meuleman, A.F.M., 1996. The vegetation N: P ratio: a new tool to detect the nature of nutrient limitation. J. Appl. Ecol. 33, 1441-1450.

Kubín, P., Melzer, A., 1996. Does ammonium affect accumulation of starch in rhizomes of Phragmites australis (Cav.) Trin. Ex Steud.? Folia Geobot. Phytotx 31, 99-109.

Kubín, P., Melzer, A., Čížková, H., 1994. The relationship between starch content in rhizomes of Phragmites australis (Cav.) Trin. ex Steud. and trophic conditions of habitat. P. Roy. Soc. Edinb. B 102, 433-438.

Kühl, H., Woitke, P., Kohl, J.-G., 1997. Strategies of nitrogen cycling of Phragmites australis at two sites differing in nutrient availability. Int. Rev. Ges. Hydrobiol. 82, 57-66.

Lawniczak, A.E., Zbierska, J., Choiński, A., Szczepaniak, W., 2010. Response of emergent macrophytes to hydrological changes in a shallow lake, with special reference to nutrient cycling. Hydrobiologia 656, 243-254.

Lenssen, J.P.M., Menting, F.B.J., van der Putten, W.H., Blom, C.W.P.M., 1999. Control of plant species richness and zonation of functional groups along a freshwater flooding gradient. Oikos 86, 523-534.

Lippert, H., Rolletschek, H., Kühl, H., Kohl, J.-G., 1999. Internal and external nutrient cycles in stands of Phragmites australis - a model for two ecotypes. Hydrobiologia 408/409, 343-348.

Lövstedt, C., Larson, M., 2010. Wave damping in reed: field measurements and mathematical modeling. J. Hydraul. Eng. 136, 222-233.

Ludwig, D.F., Iannuzzi, T.J., Esposito, A.N., 2003. Phragmites and environmental management: a question of values. Estuaries 2B, 624-630.

Mochnacka-Lawacz, H., 1974. The effects of mowing on the dynamics of quantity, biomass and mineral contents of reed (Phragmites communis Trin.). Pol. Arch. Hydrobiol. 21, 381-386.

Olde Venterink, H., van der Vliet, R.E., Wassen, M.J., 2001. Nutrient limitation along a productivity gradient in wet meadows. Plant Soil. 234, 171-179.

Ostendorp, W., 1993. Schilf als Lebensraum. Beih, 68. Veröff. Naturschutz Landschaftspfl, Bad.-Württ, pp. 173-280.

Ostendorp, W., 1999. Susceptibility of lakeside Phragmites reeds to environmental stresses: examples from Lake Constance-Untersee (SW-Germany). Limnologica 29, 21-27.

Poulin, B., Davranche, A., Lefebvre, G., 2010. Ecological assessment of Phragmites australis wetlands using multi-season SPOT-5 scenes. Remote Sens. Environ. $114,1602-1609$

Poulin, B., Lefebvre, G., Mauchamp, A., 2002. Habitat requirements of passerines and reedbed management in southern France. Biol. Conserv. 107, 315-325.

Price, J., Rochefort, L., Quinty, F., 1998. Energy and moisture considerations on cutover peatlands: surface microtopography, mulch cover and Sphagnum regeneration. Ecol. Eng. 10, 293-312.

Próchnicki, P., 2005. The expansion of common reed (Phragmites australis (Cav.) Trin. ex Steud.) in the anastomosing river valley after cessation of agriculture use (Narew River valley, NE Poland). Pol. J. Ecol. 53, 105-111.

Reale, L., Gigante, D., Landucci, F., Ferranti, F., Venanzoni, R., 2012. Morphological and histo-anatomical traits reflect die-back in Phragmites australis (Cav.) Steud. Aquat. Bot. 103, 122-128.

Rogora, M., Garibaldi, L., Morabito, G., Arisci, S., Mosello, R., 2002. Present trophic level of Lake Alserio (Northern Italy) and prospect for its recovery. J. Limnol. 61, $27-40$.

Rolletschek, H., Rolletschek, A., Hartzendorf, T., Kohl, J.-G., 2000. Physiological consequences of mowing and burning of Phragmites australis stands for rhizome ventilation and amino acid metabolism. Wetl. Ecol. Manage. 8, 425433.

Roth, S., Seeger, T., Poschlod, P., Pfadenhauer, J., Succow, M., 1999. Establishment of helophytes in the course of fen restoration. Appl. Veg. Sci. 2, 131-136.

Ruiz, M., Velasco, J., 2010. Nutrient bioaccumulation in Phragmites australis: management tool for reduction of pollution in the Mar Menor. Water Air Soil. Pollut. 205, 173-185.

Russell, I.A., Kraaij, T., 2008. Effects of cutting Phragmites australis along an inundation gradient, with implications for managing reed encroachment in a South African estuarine lake system. Wetl. Ecol. Manage. 16, 383-393. 
Saltmarsh, A., Mauchamp, A., Rambal, S., 2006. Contrasted effects of water limitation on leaf functions and growth of two emergent co-occurring plant species, Cladium mariscus and Phragmites australis. Aquat. Bot. 84, 191-198.

Schank, J.C., Koehnle, T.J., 2009. Pseudoreplication is a pseudoproblem. J. Comp. Psychol. 123, 421-433.

Toet, S., Bouwman, M., Cevaal, A., Verhoeven, J.T.A., 2005. Nutrient removal through autumn harvest of Phragmites australis and Typha latifolia shoots in relation to nutrient loading in a wetland system used for polishing sewage treatment plant effluent. J. Environ. Sci. Health. A 40, 1133-1156.

Van Duren, I.C., Pegtel, D.M., 2000. Nutrient limitations in wet, drained and rewetted fen meadows: evaluation of methods and results. Plant Soil. 220, 35-47.
Vitousek, P.M., 1982. Nutrient cycling and nutrient use efficiency. Am. Nat. 119, $553-572$.

Wang, G.K., Zhong, M.C., Wang, S.L., 2012. A meta-analysis on the response of microbial biomass, dissolved organic matter, respiration, and $\mathrm{N}$ mineralization in mineral soil to fire in forest ecosystems. For. Ecol. Manage. 271, 91-97.

Weis, J.S., Weis, P., 2004. Metal uptake, transport and release by wetland plants: implications for phytoremediation and restoration. Environ. Int. 30, 685-700.

Zhao, Y., Yang, Z., Xia, X., Wang, F., 2012. A shallow lake remediation regime with Phragmites australis: incorporating nutrient removal and water evapotranspiration. Water Res. 46, 5635-5644. 